\title{
THE NAMING OF BIRDS BY NUNAMIUT ESKIMO
}

\author{
Laurence Irving*
}

I $\mathrm{T}$ Is rare for people of two different cultures to have as good an opportunity of comparing their knowledge as Simon Paneak and I had when I was learning the Nunamiut Eskimo names for birds in the Anaktuvuk Pass region, interior arctic Alaska. The scientific list of birds of that region which I prepared provided me with a check on the completeness and accuracy of the Fskimo method of naming part of the local environment. Our relations were sufficiently close and prolonged so that we could both ascertain that we were designating the same birds by our Eskimo and English names.

The English names of birds used in this study have been modified by convention of scientists to express taxonomic designations, and they are in no sense popular names. The Nunamiut names are those used by a small group of people to indicate birds in their environment. Having no knowledge of natural history in times or places outside their own small community's experience, we should not seek in the Nunamiut names for the implications of scientific taxonomy. The Eskimo preserves his names without writing or museum to serve his memory. We who depend upon written records marvel at the persistence of stable knowledge which can be fixed in oral records, but we should recall that a large degree of stability is inherent in speech.

Anaktuvuk Pass leads approximately north and south through the centre of the Brooks Range. About one hundred miles north of the arctic circle the southern border of these mountains extends from the Yukon Territory to the western arctic coast of Alaska. The mountainous band is about one hundred miles wide, with reported elevations around 10,000 feet in the east which gradually diminish toward the western coast. The northern limit of trees lies to the south of the watershed of the mountains. In the forested valleys summer rains are frequent, and deep snow remains uncompacted by wind, but in the treeless arctic mountains and on the tundra rainfall is light. The sparse snow is driven by fierce winds which bare large areas and compact the snow firmly where it lodges. In addition to the barrier of elevation, the climatic transitions of the mountain region are significant to life.

Anaktuvuk Pass preserves some of the trough-like form given by the glaciers which shaped it. Near Summit it is a valley some four or five miles wide with lowest elevations about 2,200 feet. The deeply intersected mountain walls rise steeply to nearby peaks 6,000 feet in elevation. Through this valley many migrant birds pass northward in May and early June to settle in the mountain valleys and spread over the Arctic Slope to the coast. The birds are concentrated mainly at the lowest elevations, which in this treeless area favours their observation.

*Arctic Health Research Center, U.S. Public Health Service, Anchorage, Alaska. 
A community of about sixty-five Eskimo calling themselves Nunamiut now live at Summit, where for about two years their tents have usually been centred about a post office located in Homer Mekiana's tent. This recent innovation restricts their former free movement among the mountains where they used to travel as the presence of caribou, some fishing, and availability of willow fuel dictated. They trace their origin through three generations of residence, nearly one hundred years, among the mountains. Stories of older ancestors must be called prehistoric but the Nunamiut consider themselves derived from an ancient inland people distinguished in dialect, style of clothing, and methods of hunting from Eskimo of the coast. Physical measurements show this small group to be different from some other Eskimo groups, and their present customs which vary from those on the coast add evidence for the origin which they claim in the once numerous and probably distinct inland Eskimo people (W. Irving, unpublished).

Stoney and Howard (1900) visited this area in 1885 and 1886 and spent two winters travelling among the many temporary Eskimo villages of hunters then moving about in the mountains. But in 1920 the last of the mountain Eskimo moved to the coast. As whaling and the price of furs declined this particular group of Nunamiut Eskimo left the coast and returned to resume their old life as caribou hunters in the mountains. The remainder are now nearly merged in other communities.

After Schrader's (1904) geological reconnaissance party traversed Anaktuvuk in 1901, a few prospectors and traders went through the mountains in prodigious feats of travel which have left no written record. Early air travel to the arctic coast used Anaktuvuk Pass for a route northward, and venturesome pilots explored the mountains. In particular, Sigurd Wien used to drop in to visit the Eskimo in the mountains, where he learned to rely upon the accuracy of their geographical information. It was with $\mathrm{Mr}$. Wien that I first visited the Nunamiut in 1947.

Since that time many biologists, anthropologists, teachers, traders, and sportsmen have visited Anaktuvuk for varying periods. Ingstad (1951) has written about his stay with them through the winter of 1949-50. Rausch (1951) has described the mammals of the region and the Nunamiut devices and procedures employed in their capture and utilization. William Irving (1951) has identified the finely worked small flint artifacts of an old campsite in Anaktuvuk with those found by Giddings (1951) at Cape Denbigh, Alaska, where relics of one of the oldest known American cultures were discovered.

As a result of this intercourse with strange people and new ways, the Nunamiut have been much affected. While many old ways have been superseded in the confusion of recent innovations, the older people still tenaciously preserve much of the knowledge of ancient times. But it must be sought with patience and understanding, for confusion of their thought and expression has been caused by rapid changes in their way of life.

During my first visit with the Nunamiut at Chandler Lake in November 1947 , I obtained a remarkably good idea of the avifauna of the mountains simply from long conversations in their warm skin tents. Since then I have 


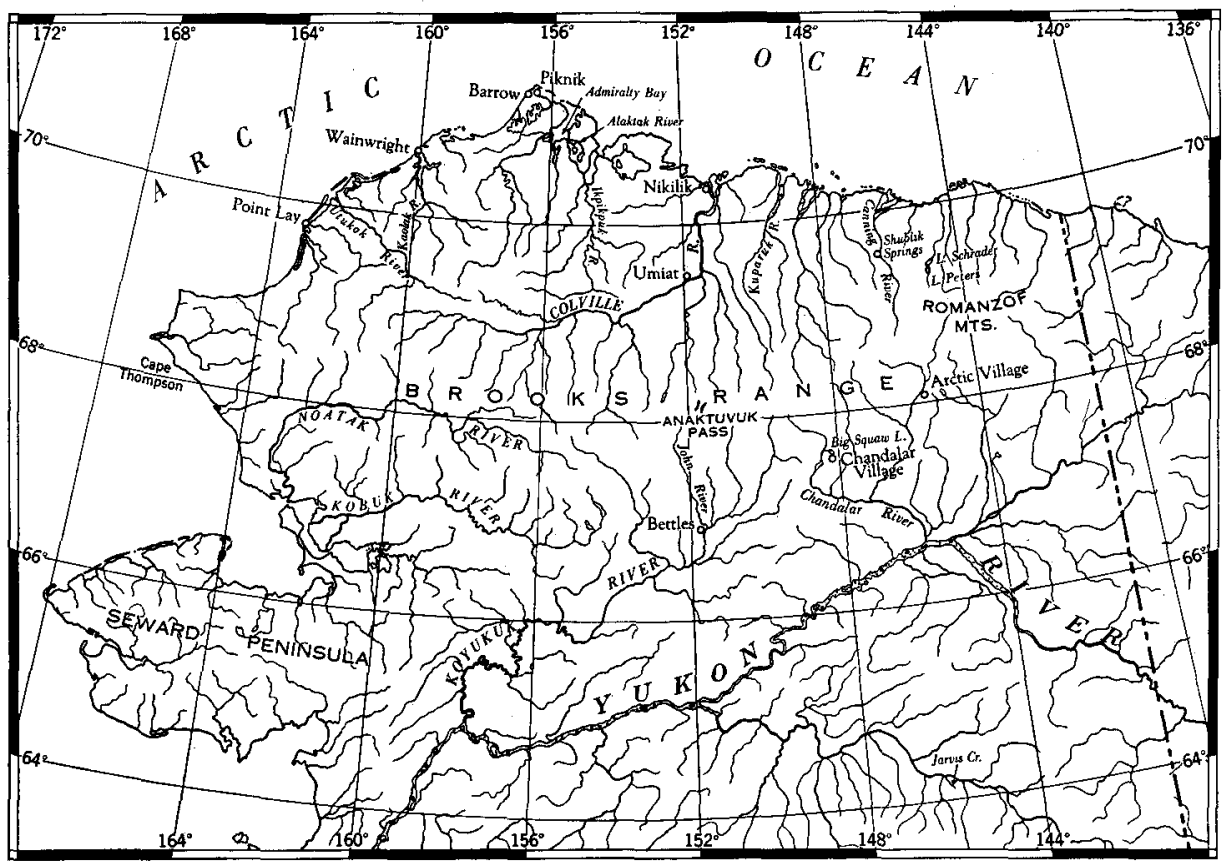

Fig. 1. Northern Alaska.

recorded many observations of birds obtained from adults and children of the village whose accuracy I could verify in our close and pleasant association. About 1,000 specimens have been transferred to the U.S. National Museum, where, with the aid of Dr. Herbert Friedmann, I have settled on the identifications of the avifauna listed in Table 1, pp. 41-3. The account of the ornithological studies will be published elsewhere.

Simon Paneak of Anaktuvuk has been my constant companion in field studies, and he has kept accurate records for me of his observations during the five years of our association. He expresses himself clearly in English marked by accurate use of a large vocabulary. In contrast with my failure to learn Eskimo, his range of expression in English has increased rapidly. As he acquired the English names of birds he has written for me the Eskimo names. From many repeated comparisons with other Nunamiut, I believe that the names which he gave are from the usage of older Nunamiut people. I have given Paneak's spelling even though it does not follow any previously used system of Eskimo transliteration, because it was consistent and proved adequate to indicate the birds both to him and to a few other Nunamiut. The most complete list of Eskimo bird names for this part of Alaska so far published (Anderson, in Stefansson, 1913) lists most of the birds given in Table 1, but only about half as many Eskimo names.

I was also greatly helped by my friend Thomas P. Brower, who, following his eminent father at Barrow, had studied and collected the birds of the arctic coast. In the early summer of 1949 he made a collection for me at Anaktuvuk 
including most of the species of birds with numerous nests. Aided by this collection, I knew about 90 forms of the avifauna at that time which now in 1952 I list at 103. The Nunamiut names of birds of Anaktuvuk with the names in English are given in Table 1; from this it can be seen that Paneak was able to name 89 of the birds. I have also included 10 birds (indicated by brackets) in this list which I had found within some fifty miles of the northern edge of the forest, but which we have never found on the treeless tundra; 7 were named by Paneak, and of the 3 for which we could not find a name, only the Bohemian Greater Waxwing was previously unknown to the Nunamiut. The name of the Ross's Gull is included in square brackets, as the single specimen observed was undoubtedly a wanderer from the arctic coast.

Some birds occasionally visit Anaktuvuk from adjacent ranges. Although these visitors are not settled in the treeless mountains their visits appear to represent a normal inclination of certain birds to explore areas within a few hours flight of their usual range. Only an Eastern White-crowned Sparrow was recorded as of accidental occurrence. It was so remote from its usual range that it could have succeeded in returning to its own kind only by a second series of accidents. On the whole the Anaktuvuk birds were very regular in time and place of appearance.

Among the birds of Anaktuvuk a few taxonomic distinctions present ornithological problems. Only close observation can distinguish between Hoary and Mealy Redpolls and between Greater and Lesser Scaup Ducks. The Nunamiut had originally one name for the two redpolls and one for the two scaups. Some of them can now distinguish the redpolls and all recognize that there are two forms of scaups. So far as I can learn they have not considered new names for these birds, using either English names or a descriptive expression which is not a true name.

I do not have specimens for determining whether there is more than one form of White-fronted Goose at Anaktuvuk. The Eskimo think of it as "the Goose", and I doubt whether from local experience only that it would be possible to realize that two forms of this goose exist.

I am sure that the following birds occur at Anaktuvuk, but explicit taxonomic treatment is as yet unclear to me: Rough-legged Hawk, Bar-tailed Godwit, and Flicker.

The Nunamiut have three names for gyrfalcons depending on the age of the birds. This special attention arose from the spectacular habits of the gyrfalcon and because of the value of their feathers. These feathers were used by the Eskimo as guides for arrows and spears and furnished the mountain people with an important commodity for trade at the coast where gyrfalcons are rare.

I could not discover Nunamiut names for the following birds which I have rarely found at Anaktuvuk: Shoveller, American Sparrow Hawk, Upland Plover, Stilt Sandpiper, Flicker, and Northern Pileolated Warbler. Simon Paneak had seen a few Shovellers on the arctic coast and the skin of a Flicker had been shown to him by his friend David Tobuk at Bettles. The other four birds were unknown to him and to the other Nunamiut. 
I could learn no Nunamiut names for the following birds which are distinctive in appearance and not rare: Northern Bald Eagle, American Herring Gull, Northern Say's Phoebe, and separate names for the Barn, Bank, and Tree Swallows.

The Nunamiut knew the Bald Eagle from their occasional travel in the forested regions and from its occasional visits northwards, but could not recall any name. Their lack of familiarity with the rather conspicuous Herring Gull is probably explained by the fact that Eskimo discard little food, hence the large gulls do not approach dwellings and are usually so shy as to make identification difficult. The Nunamiut had however occasionally reported seeing large gulls with black wing tips, but could give no name for them. The Nunamiut first recognized the Northern Say's Phoebe with me in 1950. Thereafter we found them occasionally, and they were surprised that such a distinctive bird had remained unknown to them. The three local swallows were known by one name. The more distinctive but uncommon Barn Swallow was well known, but the Bank and Tree Swallows which, although frequent visitors, are only observed in swift flight, were not distinguished until I demonstrated the difference between them.

Paneak's descriptions of old scenes have been so vivid that while listening to them I could share completely in appreciating the circumstances. These interesting narratives of his former experiences were many times repeated. When I compared his long-remembered information about places with a map or locality which I had recently seen or when I referred his accounts to events and dates recorded by scientists and explorers I found Paneak's memory precise. Although his memory and its expression are uncommonly clear even for an Eskimo, I have found that a faithful memory is a commonly cultivated faculty among them. As Simon Paneak remarked, an Eskimo keeps his map in his mind.

An instance of remarkable Eskimo memory illustrates the use of this faculty in preserving observations of nature. Paneak and I had frequently discussed the Horned Grebe and we had tentatively associated it with a bird named Malikak, which he said that his father had shot with his .44 calibre rifle on the Colville River when he was a boy, about 1907. According to his father's custom they had examined the bird carefully and after discussing its unusualness his father had told him the name. In 1951 I shot two of these grebes. When I showed them to Paneak he at once applied the name Malikak and identified them with the birds which his father had shot forty-four years earlier, but which he had not otherwise seen. Of three other men then present, one had seen Malikak many years ago on the Colville and two said they had not seen it before. The negative statements were as definite as the positive ones.

Many times Paneak and I have discussed the birds characteristic of the eastern arctic coast of Alaska which he has not seen for sixteen years. During my residence at Point Barrow I had made myself familiar with the birds of that region, and Paneak could identify all that I could describe well enough or could illustrate. He recalled the rare capture of what were probably guillemots, 
but he was certain that he had not seen auks, puffins, or cormorants. In conversation with other Nunamiut men I found no understanding of these sea birds which are so distinctive and characteristic of the Bering Sea and western arctic coasts of Alaska. To a large extent the older Nunamiut depend on information impressed on their memory by their parents and grandparents, but this knowledge is frequently reviewed in discussions. Therefore I consider that their clear knowledge of the birds of the eastern coast and their lack of knowledge of those of the western coast is significant of the experience of this Nunamiut group and of the two older generations.

A few of the Anaktuvuk people have been in Kotzebue, but they seem to have little interest in the western arctic coast. In contrast, I have listened fascinated for many hours to vivid narrative accounts by older men describing events in their earlier travels down the Colville River and eastward along the coast. Several men have been east of the Mackenzie and some sixty-five years ago Jesse Ahgook travelled among the people of the Coppermine River.

The ability to designate accurately most of the birds of their environment may be special to this particular group of Nunamiut people. I would rate their quickness of understanding and skill in social relations high even in comparison with small groups of white people who were selected for scholarly ability. These few Nunamiut families elected to withdraw from the fringes of rudely expanding white civilization to return to the enjoyment of their own way of life in the mountains, and this return required more vigour and selfreliance than to remain in the current of advancing mechanization. So these people are a selected group chosen by their special inclinations.

The Nunamiut knowledge of birds is not comparable with ornithology since they lack knowledge of natural history in other regions of the world. It is primitive in the sense that its core lay in the Nunamiut people prior to their contact with scientific methods of thinking. It seems to me though that their reliance on the memory of friends and relatives fosters attention for orderly accurate observation and vivid recollection. In our resort to written records we often put the real observations out of our minds and our names represent specimens or writing rather than birds. Whatever the processes underlying the Nunamiut naming of birds it is interesting to see how well it distinguishes those birds found in their own environment.

In addition to my acknowledgment in the text for the friendly interest of the Nunamiut people, I wish to express thanks to William Irving for his helpful companionship in the field and for critical assistance in obtaining the Nunamiut names and their meanings through his knowledge of the Eskimo language. Dr. Herbert Friedmann has made it possible for me to compare the specimens of Anaktuvuk birds with those in the collections of the United States National Museum and has reviewed the ornithological names used. Dr. Henry B. Collins, Jr. has given me much helpful criticism in the preparation of the manuscript. 
Table I. Nunamiut Eskimo names for the birds of Anaktuvuk Pass. Status of birds in the avifauna: $\mathrm{N}$-nesting, $\mathrm{M}$-migrant, $\mathrm{V}$-visitor, $\mathrm{A}$-accidental, WR-winter resident, F-forest. Names of birds of adjacent regions in brackets.

\section{English Name}

Common Loon

Yellow-billed Loon

Pacific Arctic Loon

Red-throated Loon

Horned Grebe

Whistling Swan

Taverner's Goose

Black Brant

White-fronted Goose $†$

Lesser Snow Goose

Common Mallard

American Widgeon

American Pintail

Green-winged Teal

Shoveller

Greater Scaup Duck

Lesser Scaup Duck

Old-squaw

Western Harlequin Duck

White-winged Scoter $\uparrow$

Surf Scoter

Red-breasted Merganser

(Eastern Goshawk)

American Golden Eagle

Northern Bald Eagle

American Marsh Hawk

American Osprey

American Gyrfalcon

$$
\text { " " }
$$

American Peregrine

Western Pigeon Hawk

American Sparrow Hawk

(Hudsonian Spruce Grouse)

Alaska Willow Ptarmigan

Nelson's Rock Ptarmigan

(Sharp-tailed Grouse) $\dagger$

Lesser Sandhill Crane

Semipalmated Ringed Plover

\begin{tabular}{|c|c|c|}
\hline Status & Nunamiut Name & Meaning \\
\hline NM & Tasingik & Black-billed \\
\hline VM & Tootlik & \\
\hline NM & Malirgik & \\
\hline NM & Kaksrauk & (call) \\
\hline V & Malikak & Little loon \\
\hline M & Kogruk & White \\
\hline M & Eksrahgotolik & Light-coloured cheek \\
\hline M & Niklinagak & $\begin{array}{l}\text { Almost like (White- } \\
\text { fronted) Goose }\end{array}$ \\
\hline M & Niklivik & Goose \\
\hline M & Kangok & \\
\hline NM & Ogiuguk & (call) \\
\hline NM & Koruaknak & Like pintail \\
\hline NM & Korugak & \\
\hline $\begin{array}{c}\mathrm{NM} \\
\mathrm{V}\end{array}$ & Korualorgosik & Smaller than pintail \\
\hline \multicolumn{3}{|l|}{ NM } \\
\hline $\mathrm{N}$ & Kaklutuk & Big-billed \\
\hline NM & Ahalik & \\
\hline NM & Ahaliknak & Like Old-squaw \\
\hline NM & Tongargakruk & Devil \\
\hline NM & Avilyuktok & \\
\hline NM & Akpaksruayook & $\begin{array}{l}\text { Runs (like a man) on top } \\
\text { of water }\end{array}$ \\
\hline $\mathrm{F}$ & \multicolumn{2}{|c|}{ Kidgavitch Kiringit } \\
\hline NM & Kilyirgik & Basket sled \\
\hline NM & Tikmiakpuk & Largest bird \\
\hline V & Papiktook & Long (parky) tail \\
\hline V & Kalloksioyuk & Goes after fish \\
\hline \multirow[t]{3}{*}{ NWR } & Okiotak & $\begin{array}{l}\text { The one that stays al } \\
\text { winter }\end{array}$ \\
\hline & Kitgavikroak & \\
\hline & Atkuaruak & Like caribou mittens \\
\hline NM & Kidgavitch Kiriat & Small hawk \\
\hline $\begin{array}{c}\text { NM } \\
\text { V }\end{array}$ & Kidgavitchaurak & Smallest hawk \\
\hline $\mathbf{F}$ & Napaktom Kadgia & Grouse of the trees \\
\hline NMWR & Kadgivik & Having comb on head \\
\hline NWR & Niksaktongik & The "belcher" \\
\hline$F$ & Odgillyim Kadgia & Birch grouse \\
\hline $\mathbf{M}$ & Tattidgak & \\
\hline NM & Kodrakoruk & (call) \\
\hline
\end{tabular}

Rough-legged Hawk $\dagger$

* English names used follow those of the 'American Ornithologists' Union's Check List' of North American Birds.

$\uparrow$ Subspecies not determined.

()Birds found in forested areas only. 
English Name

Northern Killdeer

Eastern American Golden Plover

Black-bellied Plover

European Turnstone

Wilson's Snipe

Hudsonian Lesser Curlew

Upland Plover

Spotted Sandpiper

Western Solitary Sandpiper

Wandering Tatler

Lesser Yellow-legs

Pectoral Sandpiper

Baird's Sandpiper

Least Sandpiper

Red-backed Dunlin

Long-billed Dowitchet

Stilt Sandpiper

Semipalmated Sandpiper

Buff-breasted Sandpiper

Bar-tailed Godwit $\dagger$

Sanderling

Red Phalarope

Northern Phalarope

Pomarine Jaeger

Parasitic Jaeger

Long-tailed Jaeger

Western Glaucous Gull

American Herring Gull

Short-billed Common Gull

[Ross's Gull]

Sabine's Gull

Arctic Tern

Northwestern Horned Owl

Snowy Ow1

(American Hawk Owl)

(American Great Gray Owl)

Northern Short-eared Owl

American Tengmalm's OwI

Flicker $\dagger$

Nelson's Downy Woodpecker

(Alaska Three-toed Woodpecker)

Northern Say's Phoebe

Pallid Horned Lark

Tree Swallow

Common Bank Swallow

Barn Swallow

Alaska Gray Jay

Northern Raven

Yukon Black-capped Chickadee

(Hudsonian Boreal Chickadee)

Northern Dipper

\begin{tabular}{cll} 
Status & Nunamiut Name & \multicolumn{1}{c}{ Meaning } \\
V & Talikvak & \\
NM & Todlik & (call) \\
M & Todlivak & \\
M & Talivikeak & \\
NM & Avikiak & (Sounds) like the walrus \\
M & Sigoktovak & Long-billed \\
V & & \\
V & Oklaktak & \\
M & Kipilugoksioyuk & Looks for insects \\
NM & Silyirisoktok & Like sharpening with a \\
& & stone \\
NM & Ovingoayook & The "whistler" \\
NM & Poviaktook & Inflating the chest \\
NM & Nuvuksruk & Sounds like a man with a \\
& & bad cold \\
NM & Livalivaurak & Small Liva Liva \\
M & Kayutavak & Big dipper \\
M & Kilyaktalik & Like a bundle when seen \\
& & from behind
\end{tabular}

(call)

Spotted

Having no heel

Coloured like blood

Float like a kayak

Poorly winged

Vomit

Young or new jaeger

Large gull

Beautiful gull

Kakmakloak

$\begin{array}{cll}\text { V } & \text { Kadgagiak } & \\ \text { NM } & \text { Mitkotailyak } & \text { Drooping feathers }\end{array}$

V Nukisirgak Powerful

MWR Okpik

F Neakoktoakruk Medium sized head

F Nattak

NM Nipailyutak The "screecher"

V Takpilyakruk Pretty good-sighted

$\mathrm{V}$

V Toyuk

F Toyukpuk Big Toyuk

NM

NM

V Tulugaknek Like a raven

V Tulugaknek Like a raven

V Tulugaknek Like a raven

NVWR Kirik (call)

NWR Tulugak (call)

VWR Misikakak The "jumper"

$\mathrm{F}$

NWR Anaruk Kiviruk Old woman sunk 
English Name

Eastern Robin

Northern Gray-cheeked Thrush

European Wheatear

Kennicott's Arctic Willow Warbler

(Eastern Ruby-crowned Kinglet)

Alaska Yellow Wagtail

American Water Pipit

(Bohemian Greater Waxwing)

Alaska Great Shrike

Northern Pileolated Warbler

Rusty Blackbird

Alaska Pine Grosbeak

Gray-crowned Rosy Finch

Coues's Hoary Redpoll

\section{Mealy Redpoll}

(American White-winged Crossbill)

Western Savannah Sparrow

Northern Slate-colored Junco

Western Tree Sparrow

Eastern White-crowned Sparrow

Gambel's White-crowned Sparrow

Yukon Fox Sparrow

Alaska Lapland Longspur

Smith's Longspur

Eastern Snow Bunting
Status Nunamiut Name

NM Koyapigaktoruk (song)

NM Niviolruksioyuk

NM

NM

Tikmiakpauruk

Goes after flies

Little eagle

Songakpalutunygik Small bird the colour of bile

$\begin{array}{cll}\text { F } & & \\ \text { NM } & \text { Piorgak } & \text { (call) } \\ \text { NM } & \text { Piorgavik } & \text { (call) }\end{array}$$$
\text { F }
$$

NM Irirgik Eye extractor

NV Talungiksyaurak Little raven

NVWR Kayatavak

NM Kaviksruak Refers to red colour

NMWR

$\mathrm{NM}$

F Pakagik

NM Okpisioyuk Staying mostly in willows

$\mathrm{V}$ Kayatavaurak Small grosbeak

NM Misapsak

A

NM Nungaktuakruk

NM Iklikvik Tool container

NM Potokioluk

NM Kallorgosiksook

M Amauligak
Sings with the voice of many birds

Like male eider duck, i.e., variegated black and white

\section{References}

Anderson, R. M. 1913. "Report on the natural history collections of the expeditionBirds", pp. 456-94 in Stefansson, V. 'My life with the Eskimo'. New York: $538 \mathrm{pp}$. Giddings, J. L., Jr. 1951. "The Denbigh flint complex". Amer. Antiquity, Vol. 16, pp. 193-203.

Ingstad, Helge M. 1951. 'Nunamiut, blant Alaska innlands-Eskimoer'. Oslo: $334 \mathrm{pp.}$

Irving, William. 1951. "Archaeology in the Brooks Range of Alaska". Amer. Antiquity, Vol. 17, p. 52.

Rausch, Robert. 1951. "Notes on the Nunamiut Eskimo and mammals of the Anaktuvuk Pass region, Brooks Range, Alaska". Arctic, Vol. 3, pp. 147-95.

Schrader, F. C. 1904. 'A reconnaissance in northern Alaska'. U.S. Geol. Surv. Prof. Pap. $20,139 \mathrm{pp}$.

Stoney, George M. 1900. 'Naval explorations in Alaska'. Annapolis: 105 pp. 